\title{
PERANCANGAN APLIKASI MONITORING PC BERBASIS DESKTOP PADA PROGRAM STUDI TEKNIK INFORMATIKA FAKULTAS ILMU KOMPUTER UMI
}

\author{
St. Hajrah Mansyur ${ }^{1}$, Ichroman Raditya Duwila ${ }^{2}$ \\ 1Shazwal12@gmail.com, 2ichromanrd@gmail.com \\ 1,2Universitas Muslim Indonesia
}

\begin{abstract}
Abstrak
Proses praktikum di Laboratorium Terpadu Fakultas IImu Komputer UMI adalah salah satu komponen vital dalam kegiatan belajar mengajar di Fakultas IImu Komputer UMI. Dalam melakukan praktikum di laboratorium, asisten laboratorium melakukan monitoring terhadap praktikan dengan cara standar, yaitu mengontrol dan memperhatikan aktivitas praktikan dengan langsung mendatangi PC atau komputer tempat praktikan melakukan aktivitasnya. Adanya sistem yang tanpa bantuan sebuah aplikasi monitoring sedikit menyulitkan kinerja asisten dimana harus dilakukan monitoring secara simultan. Tujuan dari penelitian ini adalah menghasilkan sebuah aplikasi yang kiranya dapat membantu asisten laboratorium untuk melakukan pengontrolan dan pengawasan terhadap praktikan. Aplikasi monitoring PC ini dibangun menggunakan bahasa pemrograman Java, editor Netbeans serta menggunakan UML dalam perancangan sistem. Hasil dari penelitian ini yaitu sebuah aplikasi monitoring yang berjalan di platform desktop dan dapat diakses oleh asisten laboratorium dimana aplikasi ini berjalan di sisi praktikan sebagai aplikasi client (berjalan di background) dan di sisi server sebagai aplikasi server.
\end{abstract}

Kata kunci: Aplikasi Monitoring, Platform Desktop, UML, Client, Aplikasi Server.

\section{Pendahuluan}

Dokumentasi aset perusahaan merupakan salah satu agenda rutin yang harus dilakukan sebagai bagian dari sistem manajemen mutu. Dokumen aset perusahaan memiliki beberapa peranan penting sebagai dokumen penunjang perusahaan semata. Sebuah dokumen (document) memuat informasi-informasi penting beserta aktivitas kegiatan yang terlibat, dalam hal ini dokumentasi aset berfungsi sebagai alat komunikasi. Melalui dokumen aset yang ada, para pengambil keputusan juga dapat menggunakannya sebagai data penunjang pengambilan keputusan masa mendatang, dalam hal ini dokumen aset difungsikan sebagai media knowledge sharing. Kegiatan dokumentasi biasanya difokuskan pada sarana dan prasarana utama yang mendukung kinerja di perusahaan tersebut [1].

Sebagai salah satu perguruan tinggi ilmu komputer terbesar di wilayah Indonesia Timur, Fakultas IImu Komputer UMI wajib memberikan pelayanan optimal kepada mahasiswa, khususnya pada ranah praktikum teknis dimana hal ini menjadi sangat penting mengingat kelas praktikum sebagai media penerapan apa yang telah dipelajari di kelas teori. Dalam praktiknya, sering ditemui kesulitan oleh para asisten laboratorium dalam melakukan pengontrolan penuh terhadap praktikan atau mahasiswa yang mengambil kelas praktikum tersebut dikarenakan banyaknya jumlah mahasiswa dalam satu kelas dan waktu praktikum yang terbatas. Maka, yang menjadi rumusan masalah disini adalah bagaimana mengatasi kesulitan asisten laboratorium dalam mengampu sebuah kelas praktikum dan mengoptimalkan pemantauan aktivitas mahasiswa di dalam kelas tersebut.

Pengembangan aplikasi monitoring berbasis Android dengan memanfaatkan teknologi web service dan windows query language bertujuan untuk memudahkan pelaksana dokumentasi untuk mendapatkan informasi perangkat keras yang dibutuhkan secara real-time menggunakan peramban maupun perangkat bergerak. Aplikasi ini dapat menyederhanakan proses dokumentasi yang cukup memakan waktu dan tenaga dengan memanfaatkan tiga komponen utama yang ada dalam penelitian ini. Windows query language akan menangani proses penarikan informasi di masing-masing perangkat komputer secara real-time begitu perangkat dinyalakan tanpa melibatkan intervensi pengguna. Teknologi web service akan bertindak sebagai protokol komunikasi data antara perangkat komputer, server, dan aplikasi klien. Sementara aplikasi disisi klien nantinya akan menjadi antarmuka bagi pengguna untuk mendapatkan informasi yang dibutuhkan. Melalui pengembangan aplikasi monitoring, proses pengumpulan data atau informasi berbasis client server memungkinkan data yang diperoleh akan terkirim secara real-time ke basis data untuk kemudian dapat diakses oleh pengguna.

Tujuan dari penelitian ini adalah merancang sebuah aplikasi monitoring yang ke depannya dapat diharapkan sebagai solusi untuk permasalahan tersebut.[2] 


\section{Metode}

\subsection{Perancangan Sistem}

Gambaran sistem yang diusulkan adalah sebagaimana diilustrasikan dalam gambar berikut.

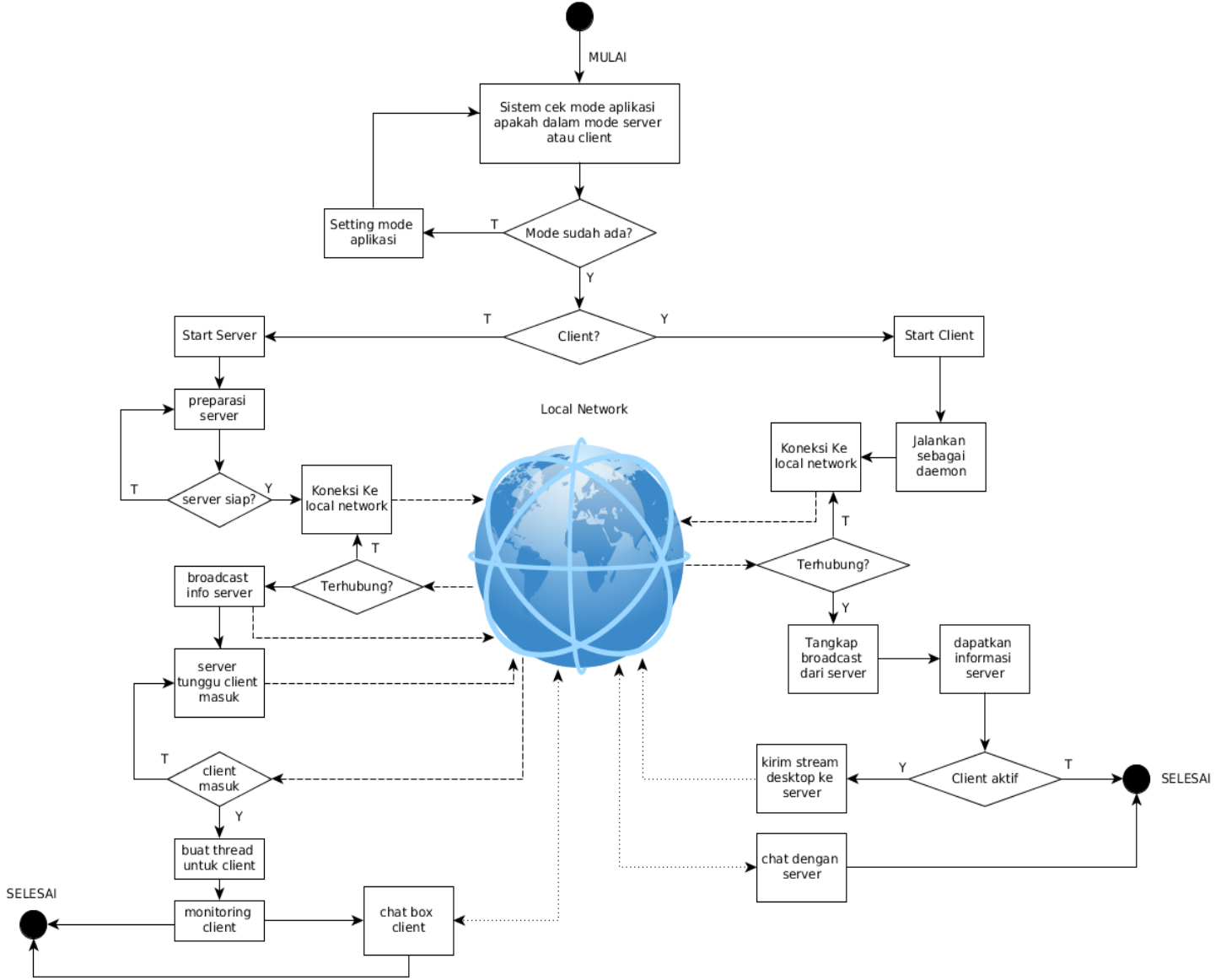

Gambar 1. Perancangan sistem baru/yang diusulkan

Sebagaimana diilustrasikan pada Gambar 1. menunjukkan aplikasi berjalan di atas jaringan lokal (via LAN atau WLAN) dan aplikasi ini terdiri atas 2 komponen, yaitu Server dan Client. Adapun protokol yang digunakan adalah protokol UDP yang berfungsi untuk melakukan broadcast kepada host-host yang ada di dalam jaringan [3]. Aplikasi yang berjalan di sisi client berjalan pada background (daemon) yang memungkinkan client mengirimkan data stream rekaman aktivitas layar kepada server secara kontinu.

\subsection{UML (Unified Modelling Language)}

Tabel 1 merupakan tabel yang berisi penjelasan dasar tentang pengguna dari aplikasi monitoring PC. Secara umum pengguna aplikasi ini terbagi atas 2 yaitu Asisten Laboratorium dan praktikan atau mahasiswa peserta praktikum [4].

Tabel 1. Identifikasi Aktor.

\begin{tabular}{|c|c|c|c|}
\hline No. & Aktor & Tipe Aktor & Aktivitas Aktor \\
\hline 1 & Asisten Laboratorium & $\begin{array}{l}\text { PSA (Primary System } \\
\text { Actor) }\end{array}$ & $\begin{array}{ll}\text { - } & \text { Melakukan monitoring kepada } \\
\text { praktikan/mahasiswa } \\
\text { - } \\
\text { Memberi warning atau pengarahan melalui fitur } \\
\text { chat } \\
\text { - } \quad \text { Memeriksa log aktivitas praktikan } \\
\text { - } \begin{array}{l}\text { melakukan blok aplikasi yang tidak sesuai dengan } \\
\text { proses belajar di laboratorium }\end{array}\end{array}$ \\
\hline 2 & Praktikan & $\begin{array}{l}\text { PBA (Primary Bussiness } \\
\text { Actor) }\end{array}$ & $\begin{array}{l}\text { - Melakukan komunikasi dengan server melalui fitur } \\
\text { chat } \\
\text { - Mengirimkan data stream aktivitas desktop } \\
(\text { daemon })\end{array}$ \\
\hline
\end{tabular}




\subsection{Use Case Diagram}

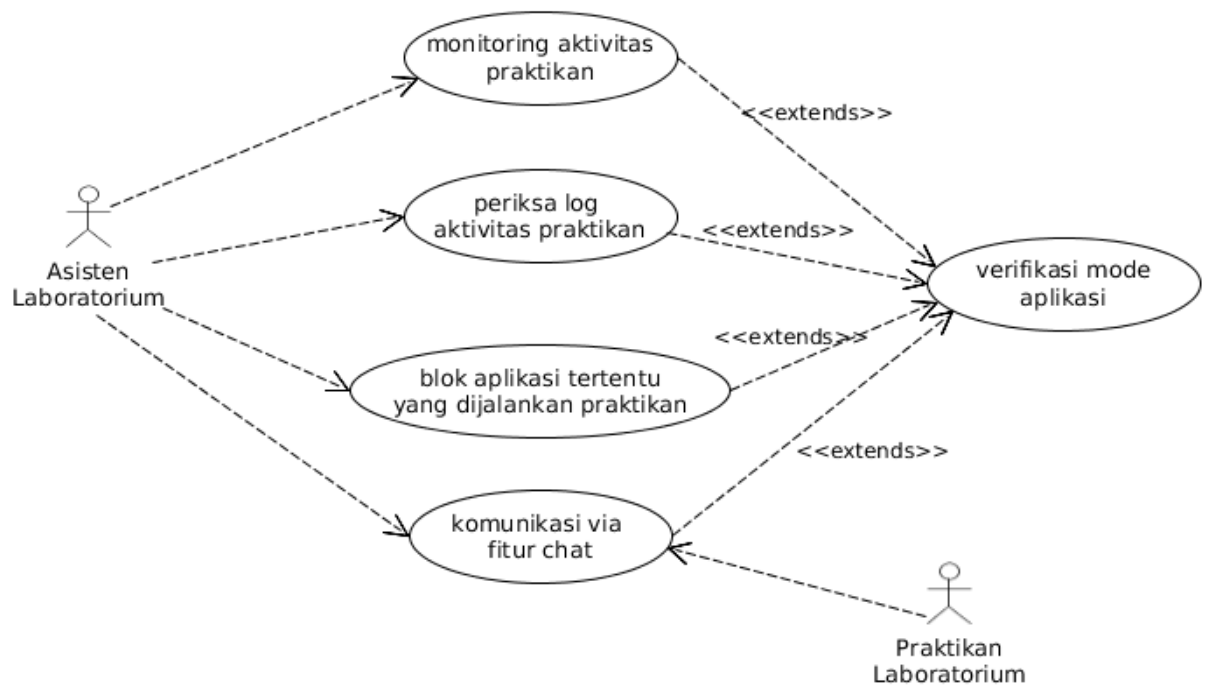

Gambar 2. Use Case Diagram Aplikasi Monitoring PC. Diagram ini adalah diagram untuk memberikan gambaran terhadap aksi yang dilakukan oleh pengguna ke pada sistem.

Pada Gambar 2 merupakan rancangan aplikasi monitoring PC yang berasitektur client-server dan berjalan di atas infrasturktur IPv4. Aplikasi terdiri dari 2 mode yaitu: mode server dan mode client. Dalam mode client, aplikasi berjalan di background atau sebagai daemon, tugasnya adalah mengirimkan capture screen dari komputer atau PC client tersebut melalui jaringan secara periodik. Sedangkan mode server menangkap hasil capture tersebut untuk kemudian ditampilkan agar dapat dilakukan monitoring terhadap aktivitasnya.

\subsection{Rancangan Antarmuka Aplikasi}

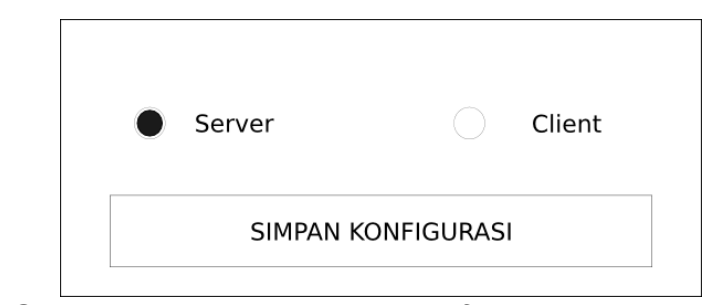

Gambar 3. Antarmuka set default mode aplikasi.

Pada Gambar 3 merupakan rancangan user interface dari pemilihan mode yang tersedia pada aplikasi. Secara default, mode yang tersedia pada aplikasi adalah mode client dan server. Mode ini dapat dipilih pada saat awal instalasi aplikasi. 


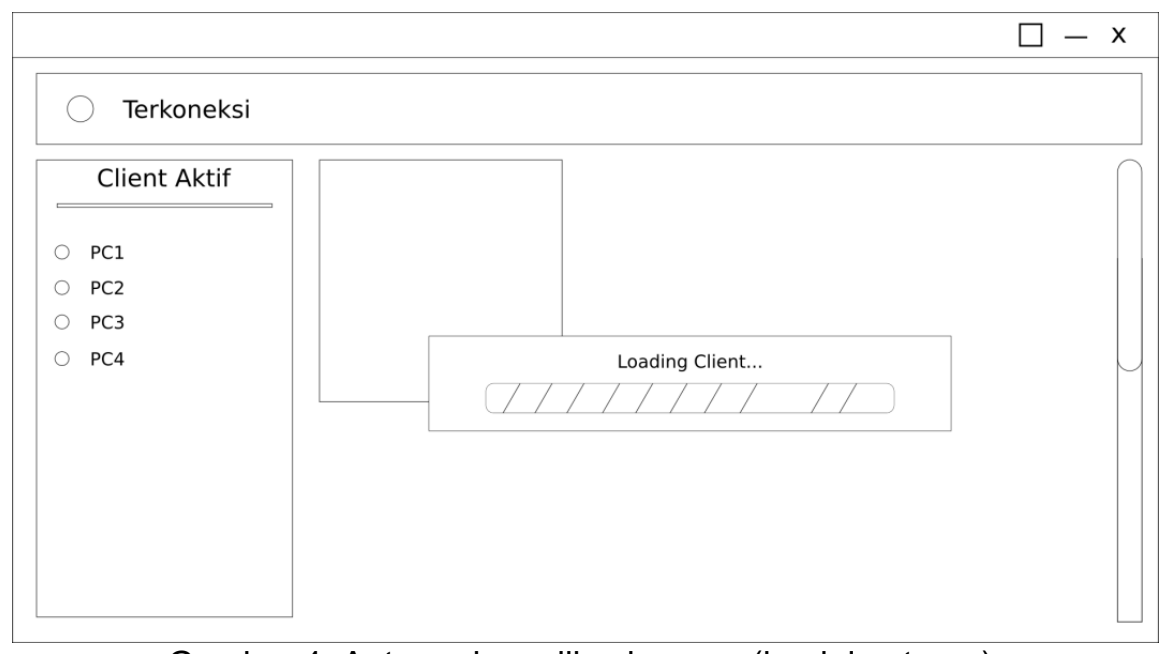

Gambar 4. Antarmuka aplikasi server (jendela utama).

Rancangan frame utama dari aplikasi monitoring PC dengan mode server ditunjukkan pada Gambar 4. Pada frame utama terdapat panel untuk melihat daftar client aktif yang terhubung ke server. Selain itu terdapat panel untuk thumbnail preview client yang aktif dan juga panel untuk status koneksi jaringan. Status koneksi jaringan akan berwarna merah jika tidak terhubung ke jaringan, dan berwarna hijau jika terkoneksi ke jaringan.

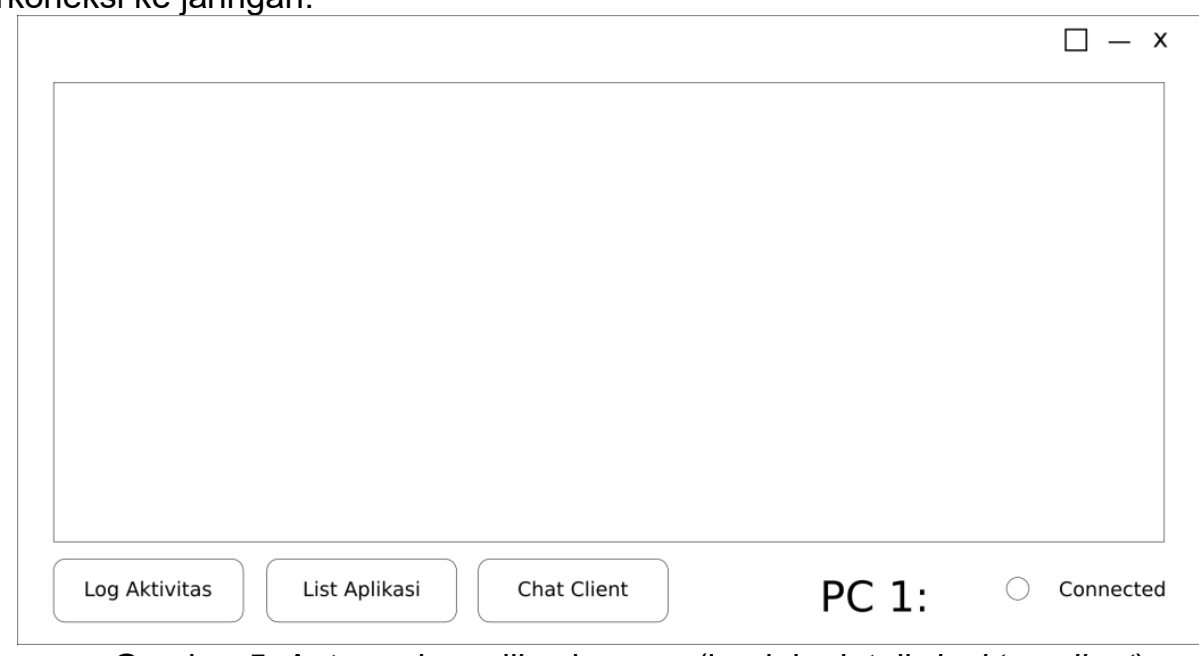

Gambar 5. Antarmuka aplikasi server (jendela detail desktop client).

Pada Gambar 5 merupakan rancangan user interface untuk setiap detail client yang di-monitoring. Pada frame ini terdapat panel sentral untuk preview hasil capture screen yang dikirim dari client. Selain itu terdapat status koneksi jaringan. Dan juga terdapat tombol untuk melihat log aktivitas client, daftar aplikasi yang sedang digunakan client dan tombol untuk membuka session chat dengan client.

\section{Hasil dan Pembahasan}

3.1 Antarmuka Aplikasi

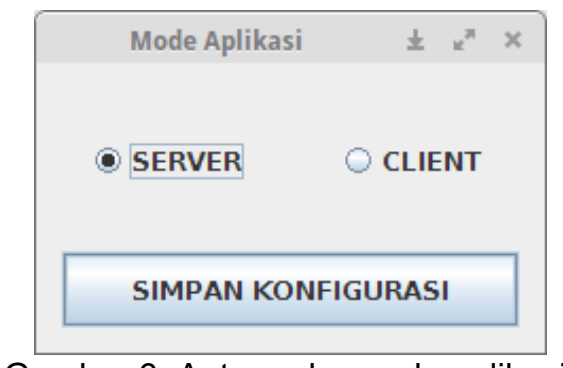

Gambar 6. Antarmuka mode aplikasi. 
Penerapan user interface dari pemilihan mode server pada aplikasi ditunjukkan pada Gambar 6 . Apabila mode client dipilih, maka frame akan menjadi tidak terlihat dan proses berjalan di background (daemon).

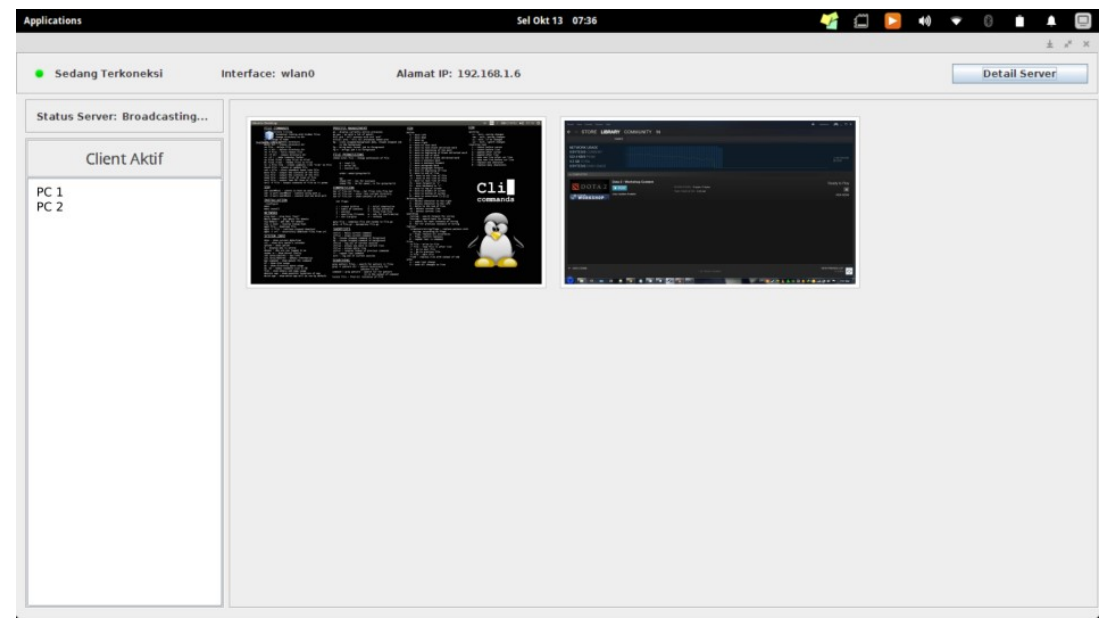

Gambar 7. Antarmuka aplikasi server.

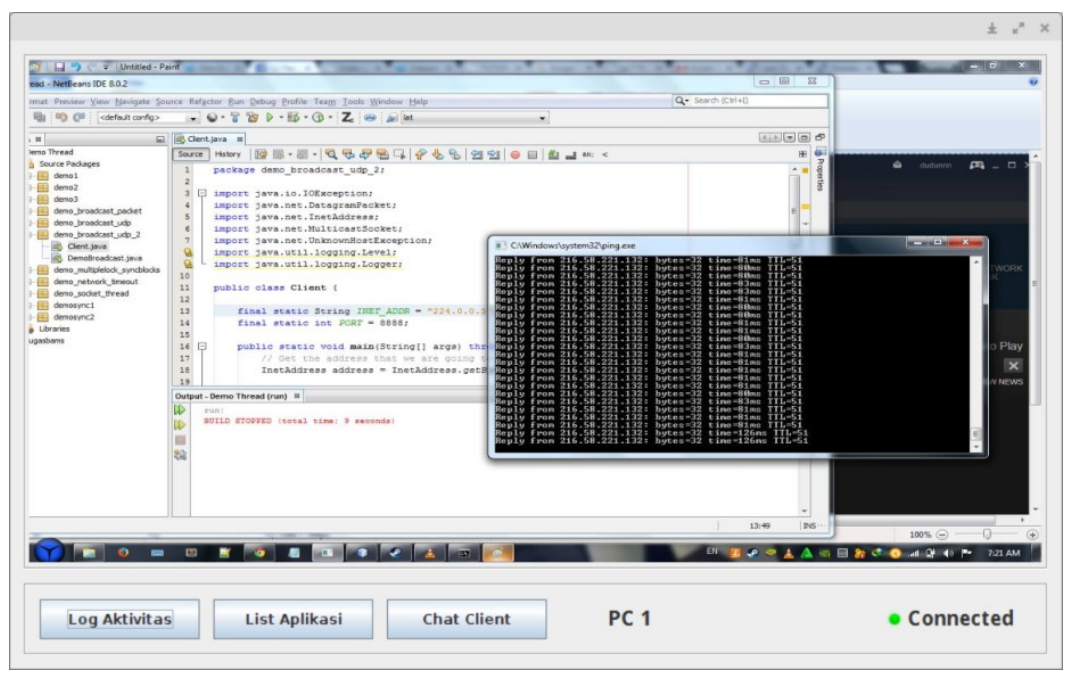

Gambar 8. Antarmuka detail remote desktop client.

Gambar 7 merupakan user interface dari frame utama aplikasi dalam mode server. Pada gambar terlihat ada 2 client yang terhubung, dengan aktivitas yang berbeda. Selain itu terdapat informasi konektivitas jaringan dan informasi IP server dan jenis network yang digunakan, yaitu wlan0 (wireless). Contoh hasil monitoring dan aktivitas client terlihat pada Gambar 8.

\subsection{Rencana Pengujian Sistem}

Pada pengujian aplikasi ini, pengujian sistem menggunakan metode pengujian black box adalah pengujian aspek fundamental sistem tanpa memperhatikan struktur logika internal aplikasi.

Pengujian adalah suatu proses pelaksanaan suatu program dengan tujuan menemukan suatu kesalahan. Suatu kasus test yang baik adalah apabila test tersebut mempunyai kemungkinan menemukan sebuah kesalahan yang tidak terungkap. Suatu test yang sukses adalah bila test tersebut membongkar suatu kesalahan yang awalnya tidak ditemukan. Salah satu dari jenis pengujian yang ada adalah Black Box Testing. Hasil pengujian menunjukkan bahwa masih terdapat banyak kekurangan saat melakukan validasi data yang akan dimasukkan, sehingga dapat menyebabkan data yang disimpan pada database tidak sesuai dengan data yang diharapkan. Hasil pengujian dapat dijadikan masukan untuk memperbaiki aplikasi Metode ini digunakan untuk mengetahui apakah aplikasi ini berfungsi dengan benar [5].

Tabel 2. Rencana pengujian aplikasi.

\begin{tabular}{|c|c|c|}
\hline Requirement yang diuji & Butir Uji & Jenis Uji \\
\hline Form Verifikasi Mode Aplikasi & Form Verifikasi Mode Aplikasi & Black Box \\
\hline
\end{tabular}




\begin{tabular}{|l|l|l|}
\hline & $\begin{array}{l}\text { berfungsi sebagai penentuan mode } \\
\text { aplikasi apakah berfungsi sebagai } \\
\text { server atau client }\end{array}$ & Black Box \\
\hline Form Utama (server) & $\begin{array}{l}\text { Form Utama berfungsi sebagai form } \\
\text { dashboard atau form administrasi } \\
\text { user (server/asisten laboratorium) }\end{array}$ & Black Box \\
\hline Form Detail Monitoring Client & $\begin{array}{l}\text { Form Detail Monitoring Client adalah } \\
\text { form untuk melihat detail aktivitas } \\
\text { client }\end{array}$ & \\
\hline
\end{tabular}

Tabel 2 berisi informasi data untuk pengujian yang menggunakan pengujian Black box. Terdapat 3 (tiga) tahapan pengujian yang telah dilakukan, yaitu Form Verifikasi Mode Aplikasi, Form Utama (Server) dan Form Detail Monitoring Client.

\subsection{Kasus dan Hasil Pengujian}

Berikut ini uraian hasil dengan teknik pengujian black box berdasarkan requirement pada rencana pengujian. Untuk lebih jelasnya akan dijelaskan dibawah ini. Pengujian semua menu merupakan pengujian fungsionalitas dengan memilih menu.

Tabel 3. Kasus Pengujian.

\begin{tabular}{|c|c|c|c|}
\hline \multicolumn{4}{|c|}{ Kategori } \\
\hline Skenario Uji & Hasil yang diharapkan & Pengamatan & Hasil Pengujian \\
\hline $\begin{array}{l}\text { Form Verifikasi Mode } \\
\text { Aplikasi }\end{array}$ & $\begin{array}{l}\text { Setelah memilih mode } \\
\text { aplikasi maka akan } \\
\text { muncul halaman form } \\
\text { utama (server) jika } \\
\text { memilih mode server } \\
\text { dan akan berjalan } \\
\text { sebagai daemon } \\
\text { (background proces) } \\
\text { jika memilih mode } \\
\text { client. }\end{array}$ & $\begin{array}{l}\text { Fungsi berjalan sesuai } \\
\text { denagn yang } \\
\text { diharapkan. }\end{array}$ & $\begin{array}{l}\text { [v] diterima } \\
\text { [] ditolak }\end{array}$ \\
\hline Form utama (server) & $\begin{array}{l}\text { 1. Menampilkan status } \\
\text { koneksi (terhubung ke } \\
\text { jaringan lokal) } \\
\text { 2. Menampilkan panel } \\
\text { remote apabila ada } \\
\text { client yang terhubung } \\
\text { 3. Menampilkan list } \\
\text { client yang terhubung } \\
\text { dengan server }\end{array}$ & $\begin{array}{l}\text { Fungsi berjalan sesuai } \\
\text { dengan yang } \\
\text { diharapkan. }\end{array}$ & $\begin{array}{l}\text { [v] diterima } \\
\text { [] ditolak }\end{array}$ \\
\hline $\begin{array}{l}\text { Form Detail Monitoring } \\
\text { Client }\end{array}$ & $\begin{array}{l}\text { Menampilkan aktivitas } \\
\text { client secara remote }\end{array}$ & $\begin{array}{l}\text { Fungsi berjalan sesuai } \\
\text { dengan yang } \\
\text { diharapkan. }\end{array}$ & $\begin{array}{l}\text { [v] diterima } \\
\text { [] ditolak }\end{array}$ \\
\hline
\end{tabular}

Tabel 3 merupakan informasi untuk kasus pengujian yang dilakukan dengan maksimal 2 PC sebagai sampel atau contoh. Adapun 3 (tiga) tahapan scenario uji yang dilakukan yaitu Form Verifikasi Mode Aplikasi, Form utama (server), dan Form Detail Monitoring Client. Sehingga berdasarkan pengujian yang dilakukan diperoleh hasil fungsi berjalan sesuai yang diharapkan dengan delay sebanyak 5 detik dengan ping rate sebesar $50 \mathrm{~ms}$.

\section{Kesimpulan dan Saran}

\subsection{Kesimpulan}

Dari keseluruhan pembuatan tugas akhir ini dapat disimpulkan bahwa aplikasi ini telah dapat melakukan monitoring PC secara maksimal dengan menggunakan jaringan ethernet.Meskipun begitu masih terdapat kekurangan pada aplikasi ini, yakni apabila lalu lintas jaringan sibuk maka transfer-rate pada aplikasi menjadi lambat yang menyebabkan delay pada saat menampilkan screen dari PC client. 


\subsection{Saran}

Dengan keterbatasan kemampuan dan waktu yang tersedia penulis menyadari masih banyak kekurangan dalam Perancangan Aplikasi Monitoring PC Berbasis Desktop ini. Ke depan diharapkan nantinya dalam pengembangan aplikasi ini, penulis menyarankan untuk mengurangi delay runtime video antara client dengan server sehingga lebih mengefisiensikan waktu bagi penggunanya kelak. Salah satu cara yang mungkin ditempuh adalah menggunakan protokol selain UDP atau melakukan perbaikan topologi jaringan.

\section{Daftar Pustaka}

[1] Irawan PLT., Abdurrachman Kamil Dhermawan, Hedry Setiawan. 2016. Rancang Bangun Aplikasi Monitoring Perangkat Keras Komputer Menggunakan Windows Query Language. Kinetik. Vol.1, No.3, Hal. 155-162.

[2] Gentisya Tri Mardiani. 2013. Sistem Monitoring Data Aset dan Inventaris PT Telkom Cianjur Berbasis Web. Jurnal Ilmiah Komputer dan informatika (KOMPUTA). Vol. 2 No. 1, Hal: 35-40.

[3] Gunawan, Chandra Arie., Setiawan, Bambang., Wibisono, Arif. 2013. Pengembangan WEBGIS Untuk Inventory Monitoring Gudang Penyangga (Studi Kasus : PT. PETROKIMIA GRESIK, ProvinsiJawaTimur).Surabaya: Jurusan Sistem Informasi, Fakultas Teknologi Informasi, Institut Teknologi Sepuluh November (ITS).

[4] Jogiyanto.1999. Analisis dan Disain Sistem Informasi Pendekatan Terstruktur Teori dan Praktek Bisnis. Andi Yogyakarta. Yogyakarta.

[5] Mustaqbal M.Sidi, Roeri Fajri Firdaus, Hendra Rahmadi. 2015. Pengujian Aplikasi Menggunakan Black Box Testing Boundary Value Analysis (Studi Kasus : Aplikasi Prediksi Kelulusan SNMPTN). Jurnal IImiah Teknologi Informasi Terapan. Vol.I, No.3. 